\title{
CONSTITUTIONAL LAW OF THE UNITED STATES AS MOULDED BY DANIEL WEBSTER.*
}

Daniel Webster was the one man in American history to whom, during his lifetime, the epithet of godlike was applied. In his case it excited no surprise. In form and feature he was like a god. The divinest of divine qualities is creative power, and that he possessed to a degree unsurpassed among lawyers. He said himself of Alexander Hamilton-"He smote the rock of the national resources and abundant streams of revenue gushed forth." It may justly be said of Webster that he touched the constitutional framework the fathers constructed and gave it life and expansiveness, so that it has continued to be adequate for the growth of the nation.

The character of the labors that fall to an American lawyer is so varied that it is impossible that any one man should perform them all. In the mother country the profession, for this reason, is divided into ranks and grades, and he who serves in one does not attempt the responsibilities of the other. As an attorney he must be a shrewd and skilful man of business; as a proctor he must be familiar with the rules of navigation; as an advocate there is no height of intellectual attainment to which he may not aspire, and no resource or learning, or power of persuasive or judicial eloquence which will not aid him in his daily task.

Again, the development of our system of jurisprudence to provide for the rapid changes in the conditions of business and social life, imposes a constant duty and labor upon the intelligent and conscientious lawyer. The law which regulated the business of a few stages and canal-boats was inadequate to direct the complicated affairs of carriers by steam on land and sea. The Judgemade Code for the carriers of articles that could be weighed and measured had but a limited application to the companies who put at the service of the public the invisible force of electricity, and have made New York and Boston, Chicago and New Orleans parts of one great municipality. The English common law was well

* Copyright rga4 by Everett P. Wheeler. 
adapted to the thickly settled and compact island of Great Britain, but was insufficient, and in some particulars, illy adapted to the requirements of a people scattered over thirteen Commonwealths just formed into one Union. It is to the honor of the American Bar that its members have done so much to aid, and often to guide, the courts, in the development of the American common law.

There is yet another more arduous responsibility resting on the American lawyer, from which our English brethren are exempt. First among the nations we established a written Constitution which should be the Supreme Law of the Land, supreme over Executive and Legislature, and gave to the Courts of Justice the power to enforce its supremacy by declaring that a statute which had received the votes of both houses of Congress and the signature of the President should be altogether held for naught if it violated this supreme Constitution.

Well might we say, when we contemplate the magnitude of these labors, Who is sufficient for these things? No doubt now, as in the Apostles' time, there are many who pervert the word of God, of whose justice and equity Courts of Justice ought to be the visible embodiment. But, also, there are many, who like St. Paul, speak in godly sincerity, and fulfil with singleness of heart the true function of the lawyer, which is to aid the Court in the discharge of its exalted and responsible office. Preëminently such a man was Mr. Webster. He became a member of the Bar at a time when many of the most important questions, since determined, were unsettled. More than any other man, he aided in their settlement.

Coleridge tells us that "The first man upon whom the light of an idea dawned received thereby the function of a lawgiver." It was because Mr. Webster, in his capacious mind, apprehended with such clearness the idea which was the soul of the novel system our fathers established, that he was able to lead our Courts to formulate this idea in their judgments.

But it may be asked, How can this be? Is it not the duty of Judges to declare, and not to make the law? In one sense, no doubt it is. The Judge ought not to depart from the principles of the law as he finds them established. But when a case comes up, as often it does, which involves a new application of these principles or a modification of rules already settled, to adapt them to a new state of facts for which no precise provision has been or could have been made, the Judge does, in a very real and important sense, make the law, and is a lawgiver as well as a Judge. If the lawyer who presents such a case to the Court is adequate to his task, he 
must first thoroughly understand the existing rule and the reason for it; next, he must appreciate the change in circumstances and conditions which makes this in its precise form no longer applicable, and he must possess constructive ability and be able to show how the rule as it has hitherto stoad may most wisely and fitly grow to meet the requirements of the present and of the future. No man in America ever combined these qualities to a higher degree than Mr. Webster. He understood the history and character of the mother country and the law which was the necessary outgrowth of that character and history. He looked into the very heart of the American people and realized our needs. He was able to point out the path by which we could most wisely be led to our true growth and development. With unrivalled power of making hard places easy, and dark things clear, he succeeded in impressing his own convictions upon the Courts before whom he practiced.

Even amid the absolute precision of mathematics, great minds can see what lesser minds fail to pierce. What they see they can make clear. The truths which Newton and La Place were the first to behold and develop can now be taught to college students. And Judges many times rightly and justly laid down as law what the genius of Webster perceived and demonstrated-what without the aid of that genius might have remained undetermined. Most important of all his public service was the part he took in demonstrating the true method of construing the Constitution of the country. The very fact that this was the supreme law of the land, made it all the more important that its construction should be established on the right basis.

From the beginning there was a school of thinkers who sought to limit the scope of our great charter and restrain its plain provisions within narrow bounds. It is the briefest of Constitutions. Its sections and articles never undertook to provide in detail for all emergencies which might arise, but established general rules which, fairly construed, should be adequate for every occasion. If the country were to be held in bondage to the letter and disregard the spirit of the Constitution, the purpose stated in its preamble: "To form a more perfect Union," would fail of accomplishment.

No doubt there were thinkers who sought to give such a lax interpretation to its provisions that they might mean anything or nothing as the immediate occasion might seem to require, and no doubt the strict constructionists did good service in restraining the vagaries of such lax reasoners. The merit of $\mathrm{Mr}$. Webster lay in this, that he maintained the golden mean, and in numerous argu- 
ments pointed out clearly and convincingly the evils which led to the formation of the Constitution; the objects its founders sought to accomplish and the method upon which they had, upon fair rules of construction, achieved the great end they had in view.

The recent celebration of the centennial of the accession of Chief Justice Marshall to the Supreme Court of the United States has called attention to the leading part which the decisions of that Court have played in making the nation what it is. The time has come when side by side with the great name of Marshall that of Webster should be placed. The arguments of the one were as necessary as the decisions of the other. They combined to impress upon the American people a conviction of the possibilities of the country, of the fitness of the government which they had founded to enable them to make the most of these possibilities, and above all, the conviction that the thirteen colonies had become blended into one indissoluble Union.

It is hard for us to realize in the days of our greatness the weakness and insignificance of our beginnings. It frequently happens under American institutions that a man born of the humblest parents and amid the most adverse circumstances has become a man of wealth, power and influence. But the rise of the most remarkable of them all is not more extraordinary than the change which has taken place in the condition of the American people since the birth of Mr. Webster. He was born at the conclusion of the Revolutionary War and just before the treaty of peace was concluded between the thirteen colonies and the United Kingdom of Great Britain and Ireland. His father was one of the hardy settlers who had not found scope for their energies in the surroundings of their childhood and had gone into the forest, not only to discover, but really to create, a new world. The little house in Salisbury, New Hampshire, where Daniel Webster was born, on the 18th day of January, 1782, was the farthest north of any civilized dwelling in all the colonies. These were scattered along the Atlantic coast and the eastern slopes of the Alleghanies. They had neither money nor credit; were deeply in debt, with an army just about to disband, and whose meagre pay had long been in arrears. They lived under a confederation which gave the general government no real power, and which worked so badly that it left the colonies, at the end of the war, with less unity than they had at its beginning. The father of Daniel Webster had been a distinguished officer in the Revolution, and, in common with his comrades, had smarted under the weakness and incompetency and consequent injustice of the 
government of the confederation, and realized, therefore, the absclute necessity for a united and stable government if the thirteen independent colonies were ever to become a united nation.

The treaty of peace concluded at Paris, September 3, 1783, contained in its first article the following clause.

"His Britannic Majesty acknowledges the said United States, viz.: New Hampshire, Massachusetts Bay, Rhode Island and Providence Plantations, Connecticut, New York, New Jersey, Pennsylvania, Delaware, Maryland, Virginia, North Carolina, South Carolina, and Georgia."

In the breast of an American of the present day this description of his country cannot fail to awaken amusement. But the description was accurate at the time. The necessity for something better led to the calling of the convention for the forming of a new Constitution for the United States. The preamble to this instrument uses very different language. There are no words indicating that these "Independent States" were any longer to remain independent as between themselves. On the contrary, it begins as follows:

"We, the People of the United States, in order to form a more perfect Union, establish justice, ensure domestic tranquility, provide for the common defence, promote the general welfare, and secure the blessing of liberty to ourselves and our posterity, do ordain and establish this constitution for the United States of America."

In debates which took place in the conventions which were held in the different States to consider whether or not they would ratify this Constitution, the pivot on which the discussion turned was really whether this preamble expressed the national consciousness. Patrick Henry cried in Virginia: "Who gave them the right to say, "We, the People of the United States?" True enough, that right had not been conferred upon the delegates. But they assumed it, and when this assumption of authority was ratified, that which at first was but a proposition became the Constitution of a nation. The student of the constitutional history of the United States from I789 to I86I knows well that there was a constant strife between those who adhered to the old notion that the States were still what the treaty declared them to be, and those who maintained that the Constitution had welded them into a nation. One of the extraordinary statements in Senator Lodge's "Life of Webster" is that all the early fathers believed in the right of secession. No doubt some of them did. But they were not the men who were responsible 
for the Constitution.- As Mr. Webster himself said in the debate on the Force bill, February $16,1833:^{1}$

"The Constitution regards itself as perpetual and immortal. It seeks to establish a Union among the people of the States which shall last through all time, or if the common fate of things human must be expected at some period to happen to it, yet that catostrophe is not anticipated. The instrument contains ample provisions for its amendment at all times; none for its abandonment at any time. It declares that new States may come into the Union, but it does not declare that old States may go out. The Union is not a temporary partnership of States."

Rufus King, Roger Sherman, Alexander Hamilton and Benjamin Franklin knew very well what they were about when their great Constitution was published to the world. It found no warmer friend anywhere than among the old soldiers of the Revolution. These men realized the necessity of the change expressed in the preamble, and rallied to the support of the Constitution which Washington signed with as much unanimity as they had stood by him during the war. Among them none was more resolute, more thoroughly in earnest, than the father of Daniel Webster, and the son grew up amid the forests and mountains of his native State impressed with the conviction that he was a citizen of a nation. This conviction he finally impressed upon the great majority of his fellow-citizens in the Northern States and upon no small part of the people of the Southern States. It was this conviction that carried us through the Civil War. Without it, our success in that great struggle would have been impossible.

Three years after graduation and on the 24th of July, I804, being then twenty-two years of age, he became a student in the office of Christopher Gore, in Boston. Mr. Gore had been a member of the United States Senate, and had been our Minister to England. Nothing shows more clearly the extraordinary effect which even then was produced by the presence of Mr. Webster, than the fact that.he, without any introduction, an absolutely unknown young man, should have been admitted into the office of one of the leaders of the Boston Bar, and one of the first men in the United States.

In March, $1805, \mathrm{Mr}$. Webster was admitted to the Bar of the Suffolk Common Pleas. In March, 1805, he opened an office at Boscawen, N. H., near his father's home, where he remained until

\footnotetext{
1 Webster's Works, Vol. 3, p. 47r,
} 
that father's death. In September, I807, he opened an office in Portsmouth, N. H. June 24, 1808 , he was married. On November I2, I8I2, he was elected to Congress, and took his seat at the extra session in the following May. In August, I814, he was re-elected to Congress from the Portsmouth District.

At the February Term of that year, he appeared for the first time as counsel before the Supreme Court of the United States. He argued two prize cases at that term and appeared in the same cases at the following term, additional proof having been ordered in both. At that time, the difficulties of travel were so great, and Washington was consequently so difficult of access, that the majority of cases in the Supreme Court of the United States were argued either by Members of Congress or by counsel from neighboring: States. Baltimore had a brilliant bar, and the names of Pinkney, Wirt, and Martin appear very frequent in the reports of Cranch and Wheaton.

The first appeal of real importance that Mr. Webster argued in the Supreme Court was that of the Town of Pazlet $v$. Clark. ${ }^{2}$ In this case the construction of that clause of the Constitution which extended the judicial power of the United States to controversies between citizens of the same State claiming land under grants of different States, was involved. Here the strict constructionist appears on the scene, and claims that this phrase of the Constitution meant the different States that framed the Constitution, and did not apply to any States that might subsequently be admitted. Webster convinced the Court without much difficulty that this construction was too narrow, and that this clause of the Constitution, and by inference all similar clauses in that instrument, referred not only to the thirteen States which framed the Constitution, but to all which they should subsequently admit as integral parts of the Union. This seems too plain for argument now, but in those early days, when everything was in a formative condition, the decision was important, and involved within itself many of the subsequent decisions which did not appear, at the time they were made, to be so clear.

The rest of the case required a consideration of the character of the grants which had been made by the Colonial Governor of New Hampshire to the town of Pawlet, and which were precedents for the subsequent grants by the various States for educational

\footnotetext{
9 Cranch, 292.
} 
purposes. This Charter divided the land which was set apart to the town of Pawlet into sixty-eight shares, of which one was "for the incorporated Society for the propagation of the Gospel in foreign parts, one share for a glebe for the Church of England as by law established, one share for the first settled Minister of the Gospel, one share for the benefit of a school in said Town."

It was further held, after a very careful investigation of the English Ecclesiastical Law, that the town could take the land as trustee, and that where no Episcopal Church was established before the Revolution, the State could appropriate the share which had been given for this purpose by the original charter and apply it to other public uses. In this case Vermont had appropriated to the use of public schools the glebe right which had not been taken up by the Episcopal Church, and the Supreme Court sustained the validity of this statute.

Mr. Webster does not appear to have argued any cases at the February Term in 1816 . In 1817 he appeared in numerous prize cases. In 1818 he had to deal with the construction of that clause of the Constitution which described the judicial power and extended it to cases of admiralty and maritime jurisdiction. ${ }^{3}$ Here it was held that the meaning of this article was a grant, not of territory, but of jurisdiction, and that the harbors in the different States, although within the admiralty jurisdiction of the Courts of the United States, were not withdrawn from the jurisdiction of the particular State in which they happened to be situated.

And now in order I approach the case of Dartmouth College v. Woodward."

It is often said that the effect of subsequent Constitutional Amendments and general legislation has been to rob the doctrine announced in this case of much of its vitality. It is doubtless true that after this decision, in countless ways, public apprehension was aroused lest the corporations, charters for which were being granted by the Legislature, or which were incorporated under general acts, should become too strong for the people, and lest, also, applicants for the franchise might, through political favoritism, or even more ignoble methods, obtain franchises, the grant of which would be injurious to the public. Laws were passed, constitutional amendments were adopted, the object of which was to reserve to the Legislature the power to amend or repeal charters of corporations.

3. S. v. Bevans, 3 Wheaton, 336.

44 Wheaton, 518 . 
For example, the Constitution of the State of New York, framed and adopted in 1846 , Article 8, Section $I$, is as follows:

"Corporations may be formed under general laws; but shall not be created by special act, except for municipal purposes, and in cases where, in the judgment of the Legislature, the objects of the corporation cannot be attained under general laws. All general laws and special acts passed pursuant to this section, may be altered from time to time, or repealed."

But notwithstanding the endeavors that were thus made to weaken the effect and limit the scope of the decision in the Dartmouth College case, the principle upon which it was based, that of enforcing constitutional guarantees for the protection of vested rights, remains in full vigor and has been not only a safeguard, but an important element in the growth and prosperity of the American people. Wretched, indeed, is the condition of any Nation in which the peaceful citizen cannot enjoy in security the fruits of his honest labor. No system of government can justly be called a republic which does not secure to all its citizens, whether rich or poor, whether engaged in individual enterprises or united with others in partnership or corporation, the protection of the law for their lawful business. The danger in every democracy has been, that in times of popular excitement this principle will be forgotten, and that the property acquired by industry and intelligence will be confiscated wholly, or in part, for the benefit of the idle and improvident. With us it is otherwise. The people of this Republic are sovereign, but they are a constitutional sovereign. Their monarchy is a limited monarchy. They have freely chosen to limit their own power by Constitutions, which they justly hold sacred. They have intrusted to the Courts of Justice, which the tradition of our race leads us to revere, the unique power of enforcing the mandate of the Constitution, and saying to the representatives of the people, whether in the Executive chair, or in the Legislature: "Thus far shalt thou go and no farther."

The system which has thus been described has become incorporated in the mental constitution of the American people. They seldom realize the difference between this and other so-called republics. But when we come to trace the history of our system and observe the manner in which the scheme, which looked well on paper, came actually to be worked out and realized in action, we find that the difference of which I speak was in great measure due to the argument of Mr. Webster in the Dartmouth College case and 
to the decision of the Supreme Court which crowned that argument.

That case was begun in the Supreme Court of New Hampshire. The contention was between the trustees of Dartmouth College, appointed under the provisions of its charter, and the trustees appointed by act of its Legislature, which changed that charter without the consent of the college.

In the argument before the Supreme Court of New Hampshire, reference was made by the counsel for the college to the provisions of the Bill of Rights of that State, which were really derived from Magna Charta:

"That no person shall be deprived of his property, immunities or privileges, put out of the protection of the law, exiled or deprived of his life, liberty or estate, but by judgment of his peers or by the law of the land."

The Supreme Court of New Hampshire decided that the trustees had no property, immunities, liberty or privileges in the corporation, within the scope of this prohibition in the Bill of Rights. Chief Justice Richardson went further and maintained "that the law of the land meant any law that the Legislature might choose to enact." In other words, he contended that the object of these provisions was to protect only against the arbitrary action of the Executive.

It will at once be perceived that this question was fundamental. The Court of New Hampshire had said:

"How a privilege can be protected from the operation of the law of the land, by a clause in the Constitution declaring that it shall not be taken away, but by the law of the land, is not very easily understood."

The difficulty in the case as it was presented to the United States Supreme Court was this: That Court had no jurisdiction upon the writ of error to review the decision of the State Court upon its own Constitution. The writ of error was based solely upon the alleged invalidity of the act of the Legislature of New Hampshire under the Constitution of the United States. The guarantee of the State Constitution was so much more explicit, that to the ordinary lawyer it would appear a hopeless task to sustain the contention under the United States Constitution, when that of the State Bill of Rights had proved to be inadequate. It was the business of the great lawyer to go below the surface of his case and to show that the fundamental error of the opinion of the Court below was equally fatal to the validity of the act under either Constitution. To this end, and to this end only, it became important at the outset 
of Mr. Webster's argument in the Supreme Court, to use the Constitution of New Hampshire as an illustration, and to show in fact that the opinion or method of reasoning which had been adopted by the Court below was fatal to any constitutional guarantee either to person or to property. For if the act of the Legislature was in itself the law of the land, and its inscription on the statute book was the limit of inquiry as to what the law of the land might be, the restraint of the Constitution upon the Legislature would be removed altogether.

The story is, that when the Chief Justice looked at the record, his first impression was adverse to the plaintiffs in error. But it is related that although he and others of the Justices had prepared to take notes of the argument of Mr. Webster, yet it seemed so clear and convincing as it flowed in its majestic course, that the paper remained blank.

After stating the facts of the case, Mr. Webster referred to the provisions of the State Constitution. He says:

"I am aware of the limits which bound the jurisdiction of the Court in this case and that on this record nothing can be decided, but the single question, whether these acts are repugnant to the Constitution of the United States. Yet it may assist in forming an opinion of their true nature and character, to compare them with these fundamental principles, introduced into the State governments for the purpose of limiting the exercise of the legislative power, and which the Constitution of New Hampshire expresses with great fullness and accuracy."

He then proceeded to argue that a corporate franchise was property. He cited numerous English cases in which such franchise had been recognized as property, and had been held to confer rights which the Courts were bound to respect. He showed that the word "liberties," used in Magna Charter, included a franchise, and that this franchise could not be taken away by arbitrary government. He showed that while under the Roman laws the will of the Prince was paramount, and he even had the right by special decree of interpreting statutes in reference to pending cases, with us.

"The power of the law-giver is limited and defined; the judicial is regarded as a distinct independent power."

"That the Legislature shall not judge by act, it shall not decide

- Webster's Works, Vol. 5, page 468 .

- Webster's Works, Vol. 5, page 486. 
by act, it shall not deprive by act, but it shall let all these things be tried and judged by the law of the land.

"By the law of the land is most clearly intended, the general law; a law which hears before it condemns; which proceeds upon inquiry, and renders judgment only after trial. The meaning is, that every citizen shall hold his life, liberty, property and immunities under the protection of the general rules which govern society. Everything which may pass under the form of an enactment, is not therefore to be considered the law of the land. If this were so, acts of attainder, bills of pains and penalties, acts of confiscation, acts reversing judgments, and acts directly transferring one man's estate to another, legislative judgments, decrees and forfeitures in all possible forms, would be the law of the land."

"If then the franchise of a corporation be property, this property is a creation of a grant. To this grant, there are two parties; the charter must be accepted, the acceptance of the grant constitutes the contract.

"There are, in this case, all the essential constituent parts of a contract. There is something to be contracted about. There are parties, and there are plain terms in which the agreement of the parties on the subject of the contract, is expressed. There are mutual considerations and inducements. The charter recites that the founder, on his part, has agreed to establish his seminary in New Hampshire, and has to enlarge it beyond its original design, among other things, for the benefit of that province; and thereupon a charter is given to him and his associates, designated by himself, promising and assuring to them, under the plighted faith of the State, the right of governing the college, and administering its concerns in the manner provided in the charter. There is a complete and perfect grant to them of all the power of superintendence, visitation and government. Is not this a contract? If lands or money had been granted to him and his associates for the same purposes, such grant could not be rescinded. And is there any difference between a grant of corporate franchises and a grant of tangible property? No such difference is recognized in any decided case, nor does it exist in the common apprehension of mankind."8

Then Mr. Webster proceeded to answer the argument: "That abuses might arise in the management of such institutions which

'Webster's Works, Vol. 5, page 486.

- Webster's Works, Vol. 5, page 497. 
the ordinary Courts of law would be unable to correct." His reply is applicable in many another instance:

"But this is only another instance of that habit of supposing extreme cases, and then of reasoning from them, which is the constant refuge of those who are obliged to defend a cause, which, upon its merits, is indefensible."”

This was the argument. The opinion of the Court was delivered at the following term, February, 1819.

It is related that the parties in New Hampshire and their friends in other States (for the questions had been perceived to be of general importance) were dissatisfied with the argument in support of the validity of the act which Mr. Holmes of New Hampshire had made, and that Mr. Pinkney had been retained to apply for a reargument before the opinion of the Court should be delivered.

The story goes that he was present in Court at the opening of the term, but that Chief Justice Marshall designedly went on and delivered the opinion of the Court without giving Mr. Pinkney the opportunity to make the motion. This may be one of the myths that are apt to cluster around important decisions. Or the tradition may be well founded. In any case, the opponents of the college took nothing by their motion. The opinion of the Court follows closely the argument of $\mathrm{Mr}$. Webster. It states at the outset:

"That the framers of the Constitution did not intend to restrain States in the regulation of their civil institutions adopted for internal government, and that the instrument they had given us was not to be so construed, may be admitted. The provision of the Constitution never has been understood to embrace other contracts than those that respect property, or some object of value, and confer rights which may be asserted in a Court of Justice."10

The Court then proceeded to show that an educational institution founded by individuals and endowed by them is not a public institution. Its trustees are not public officers, its professors and students are not members of the civil government.

"The charter is a contract to which the donors, the trustees and the Crown (to whose rights. and obligations New Hampshire succeeds), were the original parties. It is a contract made on a valuable consideration. It is a contract for the security and disposition of property. It is a contract, on the faith of which, real and personal estate has been conveyed to the corporation. It is then a

'Webster's Works, Vol. 5, page 498.

${ }^{20}$ Dartmouth College v. Woodward, 4 Wheaton, 485-629. 
contract within the letter of the Constitution, and within its spirit also, unless the fact that the property is invested by the donors in trustees, for the promotion of religion and education, for the benefit of persons who are perpetually changing, though the objects remain the same, shall create a particular exception, taking this case out of the prohibition contained in the Constitution."11

The opinion then proceeded to inquire as to the relation of the State of New Hampshire to the case, and holds that this State succeeded to the rights of the Crown in the grant and that all contracts and restrictions on property remain unchanged by the Revolution. The franchises which had been granted to Dartmouth College remained the same under the new as they were under the old government, subject to the limitations found in the Constitution of the State and of the United States. It was then held that the act in question, if enforced, would substantially change the contract and transfer the whole power of government of the college from trustees appointed according to the will of the founder to the Executive of New Hampshire.

Mr. Justice Story delivered an opinion to the same effect which contains one passage of especial interest at the present time:

"It is a principle of the common law, which has been recognized as well in this as in other Courts, that a division of an empire works no forfeiture of previously vested rights of property."

This maxim is equally consistent with the common sense of mankind and the maxims of eternal justice.

In this connection it should be added that the effect of reservation by the State of the right to alter, modify, or repeal a charter of a corporation, has become a subject of frequent consideration. The limit of these powers is well stated by the Supreme Court of the United States in Miller $v$. the State. ${ }^{12}$

"Power to legislate founded upon such a reservation in the charter of a private corporation is certainly not without limit, and it may well be admitted that it cannot be exercised to take away or deprive rights acquired by virtue of such a charter, and which, by the legitimate use of the powers granted, has become vested in the corporation."

In People v. O'Brien, ${ }^{13}$ it was held:

II 4 Wheaton, pages $493-644$.

I2 15 Wallace, 478.

13 II N New York, I. 
"That a franchise to construct and operate a railroad was property, and transferable as such. That while the Legislature under the reservation under the Constitution in the State of New York might repeal and dissolve the corporation, it could not deprive the creditors and stockholders of the corporation of their interest in this franchise, and that, therefore, this franchise would pass to a receiver of the corporation."

A curious illustration of Mr. Webster's argument that, if abuses were found to exist in corporate management, the Legislature had ample power to deal with them, is to be found in the legislation of New York in reference to taxes 1pon corporate franchises. ${ }^{14}$ No doubt in many cases such franchises have been granted upon an inadequate consideration. It is obvious that the smaller the consideration for a particular franchise, the greater is the value to the corporation possessing it. Therefore, the Legislature, by authorizing the taxing a franchise at its full value, can redress the injustice of the original grant.

In a subsequent case in which $\mathrm{Mr}$. Webster was counsel-Society for the Propagation of the Gospel in Foreign Parts $v$. Tozen of New Haven $^{15}$ - the rights of this venerable society came further under consideration by the Court. It was held that the charter which reserved to that society a share of the town lands vested an interest in the society which the Legislature of Vermont had no power to divest. This really was an application of the principles of the Dartmouth College case.

Important as were the cases to which reference has already been had, it may be doubted whether either of them were of more consequence to the country than the decision in Gibbons v. Ogden. ${ }^{16}$

In 1807 Robert Fulton had constructed a steamboat named "The Clermont" (after Chancellor Livingston's country seat on the banks of the Hudson), which made a successful voyage from New York to Albany, to the great astonishment of the people on the banks of the river. Afterwards, when slow communication by coach and sailing vessel had made the great event known abroad, it became the admiration of the civilized world.

John Fitch had made a small steamboat which had moved about on the Collect Pond in New York City, where now the City Prison

"People ex rel. Metropolitan St. R. R. Co. v. Tax Commissioners, 174 N. Y., 4I\%.

Is 8 Wheaton, 464 .

${ }^{28} 9$ Wheaton, 1 . 
is constructed. The Legislature in 1787 granted to him the sole and exclusive right of making and using every kind of boat or vessel impelled by steam in all the waters within the jurisdiction of New York for fourteen years. But Fitch had not the capital, and perhaps not the skill to develop his invention and put it in practical operation. Meanwhile, Robert Fulton, a native of Pennsylvania, a son of an Irish immigrant, had been studying the question of the steamboat and had gone to France and endeavored to interest the First Consul in his plan. This was referred to the Institute for examination, but that learned body did not seem to think the subject worth its attention. Meanwhile, the United States had sent Robert R. Livingston as Minister to France. He had been experimenting in New York in the same direction. In 1798 , he obtained from the Legislature of that State an act which, on the suggestion that "Fitch was dead or had withdrawn from the State without having made any attempt to use his privilege," repealed the grant to him and conferred a similar privilege on Livingston for the term of twenty years. Livingston met Fulton and the two inventors put their heads together, each benefited by what the other had done, and the result was an application to the Legislature of New York for an additional grant to them both. This was made on the $5^{\text {th }}$ day of April, 1803 , and gave them the monopoly of the use of the steamboat in New York and all its waters for twenty years from the passing of the act. After the successful trip of "The Clermont" in I807, another act was passed extending the monopoly "five years for every additional boat;" the whole duration, however, not to exceed thirty years, forbidding any and all persons to navigate the waters of the State with any steamboat or vessel without a license from Livingston and Fulton, under penalty of forfeiture of the boat or vessel.

In April, I8II, a further act was passed providing more extensive remedies, both at law and in equity, for enforcing the monopoly which had been granted to Livingston and Fulton.

Gibbons undertook to challenge this monopoly. He built a steam ferryboat, which was duly enrolled and licensed by the United States for carrying on all coasting trade, and employed it in that trade between Elizabeth in New Jersey and the city of New York. Ogden, who had a grant from Livingston and Fulton, filed a bill in the New York Court of Chancery to restrain Gibbons from the use of the boat. The Chancellor, and on appeal the Clourt of Errors, held that the acts of the State of New York under which 
Ogden claimed title were valid, and Gibbons took the case to the Supreme Court of the United States. As Mr. Webster said at the beginning of his argument:

"The laws in question, I am aware, have been deliberately re-enacted by the Legislature of New York, and they have also received the sanction, at different times, of all her judicial tribunals, than which there are few, if any, in the country, more justly entitled to respect and deference. The disposition of the Court will be, undoubtedly, to support, if it can, laws so passed and so sanctioned. I admit, therefore, that it is justly expected of us that we should make out a clear case; and unless we do so, we cannot hope for a reversal. It should be remembered, however, that the whole of this branch of power, as exercised by this Court, is a power of revision. The question must be decided by the State courts, and decided in a particular manner, before it can be brought here at all. Such decisions alone give this Court jurisdiction; and, therefore, while they are to be respected as the judgments of learned Judges, they are yet in the condition of all decisions from which the law allows an appeal."

He then proceeded, in words which cannot be abridged, to state the position of the controversy:

"By the law of New York, no one can navigate the bay of New York, the North River, the Sound, the lakes, or any of the waters of the State, by steam vessels, without a license from the grantees of New York, under penalty of forfeiture of the vessel.

"By the law of the neighboring State of Connecticut, no one can enter her waters with a steam vessel having such a license.

"By the laws of New Jersey, if any citizen of that State shall be restrained, under the New York law, from using steamboats between the shores of New Jersey and New York, he shall be entitled to an action for damages in New Jersey, with treble costs against the party who thus restrains or impedes him under the law of New York. This act of New Jersey is called an act of retortion against the illegal and oppressive legislation of New York; and seems to be defended on those grounds of public law which justify reprisals between independent States."

"It will hardly be contended that all these acts are consistent with the laws and Constitution of the United States. If there is no power in the general Government to control this extreme belligerent legislation of the States, the powers of the Government are essentially deficient in a most.important and interesting particular. The 
present controversy respects the earliest of these State laws, those of New York. On these, this Court is now to pronounce; and if they should be declared to be valid and operative, I hope somebody will point out where the State right stops, and on what grounds the acts of other States are to be held inoperative and void.

"It may be well to state again their general purport and effect, and the purport and effect of the other State laws which have been enacted by way of retaliation.

"A steam vessel of any description, going to New York, is forfeited to the representatives of Livingston and Fulton, unless she have their license. Going from New York or elsewhere to Connecticut, she is prohibited from entering the waters of that State, if she have such a license.

"If the representatives of Livingston and Fulton in New York carry into effect, by judicial process, the provisions of the New York laws, against any citizen of New Jersey, they expose themselves to a statute action in New Jersey for all damages, and treble costs."

"The New York laws extend to all steam vessels; to steam frigates, steam ferryboats, and all intermediate classes. They extend to public as well as private ships; and to vessels employed in foreign commerce, as well as to those employed in the coasting trade.

"The remedy is as summary as the grant itself is ample; for immediate confiscation, without seizure, trial, or judgment, is the penalty of infringement."17

Mr. Webster then proceeded to argue that the power of Congress to regulate commerce was complete and entire and, to a certain extent, necessarily exclusive.

The argument had been that there was a concurrent power in the States until Congress should exercise the power, which might, when exercised, exclude State government. To this Mr. Webster replied:

"I do not mean to say, that all regulations which may, in their operation, affect commerce, are exclusively in the power of Congress; but that such power as has been exercised in this case does not remain with the States.

"Nothing is more complex than commerce; and in such an age as this, no words embrace a wider field than commercial regulation.

${ }^{37}$ Webster's Works, Vol. 6, pp. 5, 6, 7. 
Almost all business and intercourse of life may be connected incidentally, more or less, with commercial regulations. But it is only necessary to apply to this part of the Constitution the wellsettled rules of construction. Some powers are held to be exclusive from words in the grant; others, from the prohibitions on the States to exercise similar powers; and others, again, from the nature of the powers themselves. It has been by this mode of reasoning that the Court has adjudicated many important questions; and the same mode is proper here. And, as some powers have been held to be exclusive, and others not so, under the same form of expression, from the nature of the different powers respectively; so where the power, on any one subject, is given in general words, like the power to regulate commerce, the true method of construction will be to consider of what parts the grant is composed, and which of those, from the nature of the thing, ought to be considered exclusive. The right set up in this case, under the laws of New York, is a monopoly. Now I think it very reasonable to say, that the Constitution never intended to leave with the States the power of granting monoplies either of trade or of navigation; and therefore, that as to this, the commercial power is exclusive in Congress. ${ }^{18}$

"It is in vain to look for an exact and precise definition of the powers of Congress on several subjects. The Constitution does not undertake the task of making such exact definitions. In conferring powers, it proceeds by the way of enumeration, stating the powers conferred, one after another, in few words; and where the power is general or complex in its nature, the extent of the grant must necessarily be judged of and limited by its object, and by the nature of the power."10

Again he adds:

"This doctrine of a general concurrent power in the States is insidious and dangerous. If it be admitted, no one can say where it will stop. The States may legislate, it is said, wherever Congress has not made a plenary exercise of its power. But who is to judge whether Congress has made this plenary exercise of its power? Congress has acted on this power; it has done all that it deemed wise; and are the States now to do whatever Congress has left undone? Congress makes such rules as, in its judgment, the case requires; and those rules, whatever they are, constitute the system.

"All useful regulation does not consist in restraint; and that

${ }^{18}$ Vol. 6, page 8.

10 Vol. 6 , page 9 . 
which Congress sees fit to leave free is a part of its regulation, as much as the rest." 20

He further argued that the obvious intent of the legislation referred to was to give preference to the citizens of some States over those of others.

"I do not mean here the advantages conferred by the grant on the grantees; but the disadvantages to which it subjects all the other citizens of New York. To impose an extraordinary tax on steam navigation visiting the ports of New York, and leaving it free everywhere else, is giving a preference to the citizens of other States over those of New York. This Congress could not do, and yet the State does it; so that this power, at first subordinate, then concurrent, now becomes paramount.

"The people of New York have a right to be protected against this monopoly. It is one of the objects for which they agreed to this Constitution, that they should stand on equality in commercial regulations; and if the Government should not insure them that, the promises made to them in its behalf would not be performed."21

It was always Mr. Webster's manner, in cases involving constitutional questions, to argue them at the outset on broad grounds. Thus, having clearly stated and defined the principles which should control the Court in deciding the case before it, he proceeded on a narrower line of argument which was open to him, namely, the contention that the license under the coasting laws which the United States had given to Gibbons was inconsistent with the legislation of New York, and that the latter must, therefore, give place to the former. It was partly on this ground that the case was finally decided, but the argument of the Court follows closely that of $\mathrm{Mr}$. Webster on the main question and adopts its fundamental propositions. To use the language of the Court:

"The appellant contends that this decree is erroneous, because the laws which purport to give the exclusive privilege it sustains, are repugnant to the Constitution and laws of the United States. They are said to be repugnant:

"I. To that clause in the Constitution which authorizes Congress to regulate commerce.

"As preliminary to the very able discussions of the Constitution which we have heard from the Bar, and as having some influence on its construction, reference has been made to the political situation

20 Vol. 6, page I8.

2 Vol. 6, page I8. 
of these States, anterior to its formation. It has been said that they were sovereign, were completely independent, and were connected with each other only by a league. This is true. But when these allied sovereigns converted their league into a government, when they converted their congress of ambassadors, deputed to deliberate on their common concerns, and to recommend measures of general utility, into a legislature, empowered to enact laws on the most interesting subjects, the whole character in which the States appear underwent a change, the extent of which must be determined by a fair consideration of the instrument by which that change was effected.

"This instrument contains an enumeration of the powers expressly granted by the people to their government. It has been said that these powers ought to be construed strictly. But why ought they to be so construed? Is there one sentence in the Constitution which gives countenance to this rule? In the last of the enumerated powers, that which grants, expressly, the means of carrying all others into execution, Congress is authorized 'to make all laws which shall be necessary and proper' for the purpose. But this limitation on the means which may be used, is not extended to the powers which are conferred; nor is there one sentence in the Constitution, which has been pointed out by the gentlemen at the Bar, or which we have been able to discern, that prescribed this rule."22

"The words are: 'Congress shall have power to regulate commerce with foreign nations, and among the several States, and with the Indian tribes.'

"The subject to be regulated is commerce; and our Constitution being, as was aptly said at the Bar, one of enumeration and not of definition; to ascertain the extent of power, it becomes necessary to settle the meaning of the word. The counsel of the appellee would limit it to traffic, to buying or selling, or to the interchange of commodities, and do not admit that it comprehends navigation. This would restrict a general term, applicable to many objects, to one of its significations. Commerce undoubtedly is traffic, but it is something more, it is intercourse. It describes the commercial intercourse between nations, and parts of nations, in all its branches, and is regulated by prescribing rules for carrying on that intercourse. The mind can scarcely conceive a system for regulating commerce between nations, which shall exclude all laws concerning

${ }^{2}$ Gibbons v. Ogden, 9 Wheaton, pp. 186-188. 
navigation, which shall be silent on the admission of the vessels of the one nation into the ports of the other, and be confined to prescribing rules for the conduct of individuals in the actual employment of buying and selling, or of barter."23

"The subject is transferred to Congress and no exception to the grant can be admitted which is not proved by the words or the nature of the thing." 24

When Mr. Webster visited Savannah, in I847, Hon. J. M. Wayne, one of the Judges of the Supreme Court, welcomed him. His address contains the following paragraph, illustrative of $\mathrm{Mr}$. Webster's influence before the most august tribunal in the United States. Judge Wayne thus addressed him.

"When the late Mr. Thomas Gibbons determined to hazard a large part of his fortune in testing the constitutionality of the laws of the State of New York, limiting the navigation of the waters of that State to steamers belonging to a company, his own interest was not so much concerned as that of the right of every citizen to use a coasting license upon the waters of the United States, in whatever way his vessel was propelled. It was a sound view of the law, but not broad enough for the occasion. It is not unlikely that the case would have been decided upon it, if you had not insisted that it should be put upon the broader constitutional grounds of commerce and navigation. The Court felt the application and force of your reasoning, and it made a decision releasing every creek and harbor, river and bay in our country from the interference of monopolies, which had already provoked unfriendly legislation between some of the States, and which would have'been as little favorable to the interests of Fulton as they were unworthy of his genius."

Two years later, in the course of his opinion in the Passenger cases $_{2}{ }^{25} \mathrm{Mr}$. Justice Wayne thus spoke of the prior decision:

"The case of Gibbons v. Ogden, in the extent and variety of learning, and in the acuteness of distinction with which it was argued by counsel, is not surpassed by any other case in the reports of Courts. In the consideration given to it by the Court, there are proofs of judicial ability, and of close and precise discrimination of most difficult points, equal to any other judgment on record. To my mind, every proposition in it has a definite and unmistakable

$\approx$ Gibbons v. Ogden, 9 Wheaton, pp. I89, I9o.

24 Ibid., 255 .

28 Howard, 437 . 
meaning. Commentaries cannot cover them up or make them doubtful.

"The case will always be a high and honorable proof of the eminence of the American Bar of that day, and of the talents and distinguished ability of the Judges who were then in the places which we now occupy.

"There were giants in those days, and I hope I may be allowed to say, without more than judicial impressiveness of manner or of words, that I rejoice that the structure raised by them for the defense of the Constitution has not this day been weakened by their successors."

The Chief Justice concluded his opinion with the following significant statement:

"Powerful and ingenious minds, taking as postulates that the powers expressly granted to the government of the Union are to be contracted by construction into the narrowest possible compass, and that the original powers of the States are retained, if any possible construction will retain them, may by a course of well digested and refined and metaphysical reasoning, founded on these premises, explain away the Constitution of our country, and leave it a magnificent structure, indeed, to look at, but totally unfit for use. They may so entangle and perplex the understanding, as to obscure principles which were thought quite plain, and induce doubts, where if the mind were to pursue its own course, none would be perceived. In such a case, it is peculiarly necessary to recur to safe and fundamental principles; to sustain those principles, and, when sustained, to make them the tests of the arguments to be examined."28

The rule for deciding constitutional questions thus laid down is a concise repetition of the more elaborate statement at the beginning of the opinion. It is a fundamental rule. It is not too much to say that the application of this rule has given the government to the country, which we now enjoy, and that we owe it to $\mathrm{Mr}$. Webster, that the conscience and judgment of the Supreme Court became satisfied that the rule referred to was the one unfailing test of the validity of a constitutional argument. This proposition became a part of the national consciousness and sustained the Nation in its great struggle from I86I to I865.

At a later period in his life, and when that sun was drawing near the horizon, which at the time of which I have just spoken, was

20ibbons v. Ogden, 9 Wheaton, p. 222. 
at meridian, Mr. Webster, with equal force of logic and power of conviction, vindicated the right of our foreign commerce to be free from exactions of States. The Passenger Tax Cases, ${ }^{27}$ as they are called, were cases in which several States, Massachusetts, New York and others, had sought to levy a tax upon every immigrant coming into their ports. The amount was not great, neither was the tax on tea. But the importance of the principle was supreme. Our Government was formed that commercial intercourse between this country and foreign countries should be open alike to all, and that no citizen or State could directly or indirectly acquire a monopoly of it, and in the decision of these cases the Court followed $\mathrm{Mr}$. Webster's argument, reversed the judgments below, and held the tax invalid.

There are many other causes which will be forever associated with the name of Webster and to which he gave the full force of his keen logic, the vivid clearness of his masterly analysis, the picturesque beauty of his felicitous statement, which in itself was argument, and above all, the power of that eloquence which he has himself so perfectly described: "The clear conception outrunning the deductions of logic, the high purpose, the firm resolve, the dauntless spirit." But time forbids. Of one more only will I speak. The Bank of Augusta against Earle as it is reported:28 The Bank of the United States against Primrose, as his argument is published in his speeches. The cases involved the same questions, were argued in succession and decided simultaneously. The decision sustained the right of a corporation chartered under the laws of one State of this Union to do business in another State, and freed associated enterprise from unjust discrimination. To curb the unlawful ambition of these associations, has fallen to the lot of a later generation. In his day the country needed strength. To-day, it needs restraint. The power and authority which he vindicated are adequate to this restraint.

To use the language of the Court in the case of the Bank of Augusta v. Earle, before referred to:

"It has, however, been supposed that the rules of comity between foreign nations do not apply to the States of this Union; that they extend to one another no other rights than those which are given by the Constitution of the United States; and that the Courts of

$\approx 7$ Howard, 437.

=s I3 Peters, 5rg. 
the general Government are not at liberty to presume, in the absence of all legislation on the subject, that a State has adopted the comity of nations toward the other States, as a part of its jurisprudence; or that it acknowledges any rights but those which are secured by the Constitution of the United States. The Court thinks otherwise. The intimate union of these States, as members of the same great political family; the deep and vital interests which bind them so closely together, should lead us, in the absence of proof to the contrary, to presume a greater degree of comity and friendship, and kindness towards one another, than we should be authorized to presume between foreign nations. And when (as without doubt must occasionally happen) the interest or policy of any State requires it to restrict the rule, it has but to declare its will, and the legal presumption is at once at an end. But until this is done, upon what grounds could this Court refuse to administer the law of international comity between these States? They are sovereign States; and the history of the past, and the events which are daily occurring, furnish the strongest evidence that they have adopted towards each other the laws of comity in their fullest extent."28

In every one of these leading cases, Webster successfully advocated the adoption of vital principles of constitutional law against the adverse decisions of the Courts below. These principles underlie our whole American system. Without them we should not have been a Nation, but a chaos of individuals. Mr. Everett tells us that what gave to La Fayette his spotless fame was "the living love of liberty protected by law." What has given to this country its greatness is its well-ordered freedom, protected and secured by the Union; Liberty secure, Union equal. No individual or citizen of one State may have privileges secured to him by law, superior to the privileges of others. On the other hand, every citizen is secured by law in the acquisition of property and in the enjoyment of his personal rights. So long as American Courts respect the principles thus established, and America combines public freedom with individual security, so long shall a grateful people cherish the memory of the expounder of the Constitution, the farmer boy of Salisbury, the eloquent, far-seeing law-giver and lawyer, DANIEL WeBster.

Everett P. Wheeler.

$\Rightarrow$ Bank of Augusta v. Earle, 13 Peters, p. 590. 